OPEN ACCESS

Edited by:

$\mathrm{Bo} \mathrm{Hu}$,

University of Minnesota, USA

Reviewed by:

Jianguo Zhang,

University of Shanghai for

Science and Technology, China

Cong Li,

Ovivo Water, USA

${ }^{*}$ Correspondence:

S. Venkata Mohan

vmohan_s@yahoo.com

Specialty section: This article was submitted to Bioenergy and Biofuels, a section of the journal Frontiers in Energy Research

Received: 25 March 2016

Accepted: 21 June 2016

Published: 10 August 2016

Citation:

Chiranjeevi $P$ and Venkata Mohan S (2016) Optimizing the Critical

Factors for Lipid Productivity during

Stress Phased Heterotrophic

Microalgae Cultivation.

Front. Energy Res. 4:26.

doi: 10.3389/fenrg.2016.00026

\section{Optimizing the Critical Factors for Lipid Productivity during Stress Phased Heterotrophic Microalgae Cultivation}

\author{
P. Chiranjeevi ${ }^{1,2}$ and S. Venkata Mohan ${ }^{1,2 *}$ \\ ${ }^{1}$ Bioengineering and Environmental Sciences (BEES), CSIR-Indian Institute of Chemical Technology (CSIR-IICT), Hyderabad, \\ India, ${ }^{2}$ Academy of Scientific and Innovative Research (AcSIR), India
}

Microalgae-derived biodiesel production is one of the promising and sustainable platform. The effect of selected stress factors $(\mathrm{pH}$, temperature, salinity, and carbon supplementation) on microalgal lipids and carbohydrate production during heterotrophic mode of operation was studied using design of experimental (DOE) methodology (Taguchi approach) with variation at four levels $\left(2^{1} \times 4^{4}\right)$. Experiments were performed with allegorical batch experimental matrix (16 experimental trails). All the selected factors showed marked influence on the lipid production, whereas temperature and carbon concentration showed major influence on the carbohydrate synthesis. Interesting, relatively higher total lipid production (55\% of DCW) was obtained from Experimental no. 6 (pH: 6; salinity: $1 \mathrm{~g} / \mathrm{l}$; temperature: $20^{\circ} \mathrm{C}$; carbon concentration: $\left.30 \mathrm{~g} / \mathrm{l}\right)$. Relatively good neutral lipid fraction (13.6\%) was observed with Experimental no. 8: $\mathrm{pH}$ : 6; salinity: 5 g/l; temperature: $30^{\circ} \mathrm{C}$; carbon concentration: $1 \mathrm{~g} / \mathrm{l}$. Good carbohydrate synthesis $(262$ mg/g biomass) was observed with Experiment no. 3 (pH: 4; salinity: $2 \mathrm{~g} / \mathrm{l}$; temperature: $30^{\circ} \mathrm{C}$; carbon concentration: $\left.15 \mathrm{~g} / \mathrm{l}\right)$. Fatty acid methyl esters (FAME) analysis the presence of higher number of saturated fatty acids (C12:0 to C24:0) in experimental setups 6 and 8 , favoring the biodiesel properties.

Keywords: biomass, chlorophyll, mixotrophic, nutritional mode, biodiesel, FAME, data envelopment analysis (DEA)

\section{INTRODUCTION}

Microalgae cultivation is attracting renewed interest due to its ability to produce diverse photosynthetic products, including lipids. Microalgae can be cultivated either by autotrophic mode (Dayananda et al., 2007; Liu et al., 2011; Venkata Mohan et al., 2011) fixing $\mathrm{CO}_{2}$ in the presence of sunlight or by heterotrophic mode (Brennan and Owende, 2010; Garcia et al., 2011; Devi and Venkata Mohan, 2012) using organic compounds as energy and carbon sources or by mixotrophic mode using both organic compounds and inorganic $\mathrm{CO}_{2}$ (Qiao and Wang, 2009; Chen et al., 2011; Devi et al., 2012; Cong and Lu-Kwang, 2014; Cong et al., 2016). At present, inherent limitations encountered with microalgae cultivation is its low lipid/biomass production, which invariably impedes its scale-up operation.

To enhance lipid synthesis, strategies by altering the nutrient regime and cultivation conditions are generally employed. Factors, such as nutrient stress, light, temperature, $\mathrm{CO}_{2}$, and salinity, have been explored to enhance lipid accumulation in microalgae (Merchant et al., 2012; Sharma et al., 2012; Chandra et al., 2014; Venkata Mohan et al., 2015; Chiranjeevi and Venkata Mohan, 2016). Stress has a critical role on the lipid synthesis during microalgae cultivation. The nutrient stress affects 
the growth of algae as well as lipid productivity and its profile. Under adverse/stress conditions, microalgae tend to accumulate neutral lipids to protect cells from photooxidation (Adams et al., 2013; Zhang et al., 2013). Among the different modes of cultivation, heterotrophic operation offers several advantages over the others, including the elimination of light requirement, and lipid yields (Devi et al., 2012; Venkata Mohan et al., 2015). Moreover, in heterotrophic mode of operation, microalgae are influenced by the stress factors facilitating synthesis of higher lipid along with significant substrate degradation (Devi et al., 2012; Cong et al., 2016).

In order to study the effect of heterotrophically induced nutrient stress on the process, design of experimental (DOE) methodology was employed. The focal objective of this investigation is to study the methodological application of Taguchi orthogonal array (OA) experimental design (DOE) to optimize selected stress factors, viz., $\mathrm{pH}$, salinity, temperature, and carbon supplementation. Factorial-based DOE methodology by Taguchi OA approach merges statistical and engineering techniques (Taguchi, 1986; Venkata Mohan et al., 2005, 2007). Mixotrophic microalgae cultivation was studied to achieve higher biomass productivity using Taguchi DOE methodology by optimizing eight factor (Chiranjeevi and Venkata Mohan, 2016).

Analysis of the experimental data using analysis of variance (ANOVA) provides information about statistically significant factors and their optimum levels.

\section{EXPERIMENTAL METHODOLOGY}

\section{Design of Experimental Methodology}

Taguchi's DOE methodology was used by selecting important factors, viz., $\mathrm{pH}$, salinity, temperature, and carbon concentration, whose variation will have a critical effect on the heterotrophic lipid synthesis and carbohydrates production (Table 1). Four levels of factor variations were selected, which represent the experimentation size of 16 with an array matrix of M-16 (Table 2).

\section{Microalgae}

Mixed microalgae culture collected from Nacharam Lake (Pedda Cheruvu), Hyderabad, during the pre-monsoon season was used as parent inoculum. The culture was washed twice with water and pelletized $(2.1 \mathrm{~g}$ with a concentration of $0.2 \mathrm{~g} / \mathrm{l})$ by centrifugation $\left(3000 \mathrm{rpm} ; 10 \mathrm{~min}\right.$ at $30^{\circ} \mathrm{C}$ ) to remove associated debris and restored in rectangular plastic tubs $(36 \mathrm{~cm} \times 24 \mathrm{~cm} \times 12 \mathrm{~cm})$ exposed to diffused sunlight. Domestic sewage [(DS) pH, 7.8; COD, $220 \mathrm{mg} / \mathrm{l}$; VFA, $165 \mathrm{mg} / \mathrm{l}$; BOD, $120 \mathrm{mg} / \mathrm{l}$; total alkalinity, $140 \mathrm{mg} / \mathrm{l}$; chlorides, $175 \mathrm{mg} / \mathrm{l}$; nitrates, $115 \mathrm{mg} / \mathrm{l}$ ] was used as feedstock for microalgal cultivation. After the consistent amount

TABLE 1 | Selected factors and assigned levels.

\begin{tabular}{llrrrr}
\hline S. no. & Factor & Level 1 & Level 2 & Level 3 & Level 4 \\
\hline 1 & pH & 4 & 6 & 8 & 10 \\
2 & Salinity $(\mathrm{g} \mathrm{NaCl} / \mathrm{l})$ & 0 & 1 & 2 & 5 \\
3 & Temperature $\left({ }^{\circ} \mathrm{C}\right)$ & 20 & 25 & 30 & 35 \\
4 & Carbon supplementation & 0 & 1 & 15 & 30 \\
& (g glucose/l) & & & &
\end{tabular}

of biomass (cell density) was achieved, this culture was used as inoculum for the experimental study.

\section{Experimental Details}

The combinatorial of 4 factors at 4 levels (Table 1) with 16 experimental variations (M-16) in batch mode (Table 2), during stress phase (SP) was performed. In accordance with the designed experiments, the $250 \mathrm{ml}$ of modified growth medium (as per design, Table 1) was sterilized (autoclaved for $20 \mathrm{~min}$ at $121^{\circ} \mathrm{C}$ and $1.05 \mathrm{~kg} / \mathrm{cm}$ steam pressure) prior to the inoculation $(10 \%$ $\mathrm{v} / \mathrm{v}$; OD, 0.1) to avoid the contamination. Growth phase (GP) was operated for a period of 8 days in mixotrophic mode [BG11 media, $\mathrm{pH}$ : 8.2 , temperature: $32^{\circ} \mathrm{C}$, glucose $1.5 \mathrm{~g} / \mathrm{l}$ and light 4000 lux]. After 8 days of growth, the cultures were harvested, and the resulting biomass was used as inoculum for the SP of the experiments operated in heterotrophic mode (Table 2). All the experimental setups were placed on a temperature shaking incubator (120 rpm). During operation (GP and SP), biomass, pigment analysis (chlorophyll $a$ and $b$ ) along with total carbohydrate concentration were estimated every alternate day. Lipid analysis was performed at initial (before the GP) and end of GP and SP. In both the phases of operations, to avoid bacterial contamination, antibiotic (ampicillin: $0.2 \mathrm{~g} / \mathrm{l}$ ) was added to each experimental setup once in every alternate day. All the experiments were carried out in triplicates, and the average of three independent operations was presented and discussed.

\section{Analysis}

Microalgae biomass was monitored by measuring OD at $600 \mathrm{~nm}$ and chlorophyll $a$ and $b$ were measured at 647 and $664 \mathrm{~nm}$, respectively. Algal cells were disrupted by sonication $(40 \mathrm{kHz}$ for 2 minutes) followed by centrifugation (5000 rpm for 5 minutes at $28^{\circ} \mathrm{C}$ ), and the dissolved carbohydrates in supernatant of the solution were estimated by Anthrone method. COD, nitrates, phosphates, and $\mathrm{pH}$ were analyzed as per standard procedure (APHA, 1998).

TABLE 2 | Orthogonal array (OA) of designed experiments with output parameters.

\begin{tabular}{|c|c|c|c|c|c|c|c|}
\hline \multirow{2}{*}{$\begin{array}{l}\text { Experiment } \\
\text { number }\end{array}$} & \multicolumn{4}{|c|}{ Factors } & \multirow{2}{*}{$\begin{array}{l}\text { Lipid } \\
\text { productivity } \\
\text { (\% of dry } \\
\text { biomass) }\end{array}$} & \multirow{2}{*}{$\begin{array}{l}\text { Neutral } \\
\text { lipid (\%) }\end{array}$} & \multirow{2}{*}{$\begin{array}{c}\text { Total } \\
\text { carbohydrates } \\
\text { (mg/g } \\
\text { biomass) }\end{array}$} \\
\hline & 1 & 2 & 3 & 4 & & & \\
\hline 1 & 1 & 1 & 1 & 1 & 14.8 & 4.7 & 144 \\
\hline 2 & 1 & 2 & 2 & 2 & 25.6 & 12.3 & 28 \\
\hline 3 & 1 & 3 & 3 & 3 & 22.1 & 11.3 & 262 \\
\hline 4 & 1 & 4 & 4 & 4 & 17.7 & 4.2 & 40 \\
\hline 5 & 2 & 1 & 2 & 3 & 49.1 & 10.9 & 28 \\
\hline 6 & 2 & 2 & 1 & 4 & 55.0 & 9.4 & 146 \\
\hline 7 & 2 & 3 & 4 & 1 & 10.6 & 4.3 & 28 \\
\hline 8 & 2 & 4 & 3 & 2 & 34.5 & 13.6 & 123 \\
\hline 9 & 3 & 1 & 3 & 4 & 45.1 & 5.7 & 235 \\
\hline 10 & 3 & 2 & 4 & 3 & 32.9 & 10.5 & 28 \\
\hline 11 & 3 & 3 & 1 & 2 & 20.6 & 5.4 & 157 \\
\hline 12 & 3 & 4 & 2 & 1 & 14.6 & 7 & 28 \\
\hline 13 & 4 & 1 & 4 & 2 & 23.2 & 6.2 & 28 \\
\hline 14 & 4 & 2 & 3 & 1 & 23.5 & 12.9 & 192 \\
\hline 15 & 4 & 3 & 2 & 4 & 20.5 & 10 & 36 \\
\hline 16 & 4 & 4 & 1 & 3 & 16 & 9.1 & 188 \\
\hline
\end{tabular}


Lipid Extraction and Derivatization of FAME

At the end of GP (2.28 g/l) and SP (1.25-10.38 g/l), the biomass was separated $\left(5000 \mathrm{rpm} ; 5 \mathrm{~min} ; 28^{\circ} \mathrm{C}\right.$ ), and the resulting biomass after solar drying was powdered by blending. The blended powder was further sonicated ( $4 \mathrm{kHz} ; 2 \mathrm{~min}$ ), and lipids was extracted using chloroform and methanol (2:1) as solvents (modified Bligh and Dyer method). Hexane was used for neutral lipid extraction (Devi et al., 2012). Furthermore, followed by centrifugation, lipid layer was transferred to pre-weighed round bottom flask, and the total and neutral lipids were determined gravimetrically in terms of percentage dry cell weight (\% DCW). Lipid productivity (\%) was calculated based on the ratio of total lipid extracted to dry weight of algal biomass. The resulted lipid was transesterified (using a methanol-sulfuric acid mixture) to fatty acid methyl esters (FAME). FAME composition was detected by gas chromatography (Nucon-5765) using FID with capillary column [30 mm $(0.25 \mathrm{~mm} \times 0.25 \mu \mathrm{m})$; Valcobond] using nitrogen carrier gas ( $1 \mathrm{ml} / \mathrm{min})$. The oven temperature was maintained initially at $140^{\circ} \mathrm{C}$ (for $5 \mathrm{~min}$ ), later increased to $240^{\circ} \mathrm{C}$ (ramp rate of $4^{\circ} \mathrm{C} / \mathrm{min}$; $10 \mathrm{~min})$. The temperature of injector and detector were maintained at 280 and $300^{\circ} \mathrm{C}$, respectively, with a split ratio of $1: 10$. The FAME composition was compared with the standard (C4- C24:1) (SUPELCO).

\section{Data Analysis}

The data derived from the experiments was analyzed employs "bigger is better" performance characteristics using Qualitek-4 (Nutek Inc.) software.

\section{RESULTS AND DISCUSSION}

\section{Growth Phase}

Mixotrophic mode of cultivation was used for microalgae cultivation during GP. Good increment in biomass growth [1.2 g/l (0 days) to $2.28 \mathrm{~g} / \mathrm{l}$ with biomass productivity of $28.5 \mathrm{mg} / \mathrm{l} /$ day (8th day)] and marginal improvement in lipid productivity [total/ neutral lipids $7.8 / 1.5$ to $12.6 / 4.4 \%$ (8th day)] was observed. In agreement to the biomass growth pattern, the total chlorophyll (TC) also increased linearly from 1.3 to $23.6 \mu \mathrm{g} / \mathrm{ml}$ by the end of GP. The organic fraction (carbon) and nutrients (nitrogen and phosphate) contributed to the accumulation of carbohydrates (total, $40 \mathrm{mg} / \mathrm{g}$ biomass) and proteins $(5.3 \mathrm{mg} / \mathrm{ml})$ at the end of the GP operation.

\section{Stress Phase}

\section{Selected Factors Influence on Lipid Synthesis}

The influence of the selected factors on stress-induced heterotrophic microalgae cultivation showed marked effect on the lipid synthesis and profile. The magnitude of the difference between average effects $(\mathrm{L} 2-\mathrm{L} 1)$ represents the relative influence of the selected factors on the process. The average effect of the factors and resulting interaction on the total and neutral lipids synthesis is depicted in Tables 3-5. The bigger the difference, the stronger is the influence (ignoring the negative value). The experiments output showed a marked variation in the lipid production as well as on its profile. Among the four factors, $\mathrm{pH}$ showed a stronger
TABLE 3 | Main effects of selected factors on total lipids production.

\begin{tabular}{lllllll}
\hline S. no. & Factor & Level 1 & Level 2 & Level 3 & Level 4 & L2 - L1 \\
\hline 1 & $\mathrm{pH}$ & 20.049 & 37.299 & 28.299 & 20.799 & 17.25 \\
2 & Salinity $(\mathrm{NaCl} \mathrm{g/l)}$ & 33.049 & 34.25 & 18.45 & 20.7 & 1.201 \\
3 & Temperature $\left({ }^{\circ} \mathrm{C}\right)$ & 26.6 & 27.449 & 31.299 & 21.1 & 0.849 \\
4 & Carbon & 15.875 & 25.974 & 30.024 & 34.574 & 10.099 \\
& supplement & & & & & \\
& (glucose g/l) & & & & & \\
\end{tabular}

TABLE 4 | Main effects of selected factors on neutral lipids synthesis.

\begin{tabular}{lllcccc}
\hline S. no. & Factor & Level 1 & Level 2 & Level 3 & Level 4 & L2 - L1 \\
\hline 1 & $\mathrm{pH}$ & 8.125 & 9.549 & 7.15 & 9.549 & 1.423 \\
2 & Salinity $(\mathrm{NaCl} \mathrm{g} / \mathrm{l})$ & 6.875 & 11.274 & 7.75 & 8.475 & 4.398 \\
3 & Temperature $\left({ }^{\circ} \mathrm{C}\right)$ & 7.15 & 10.05 & 10.875 & 6.3 & 2.9 \\
4 & Carbon & 7.224 & 9.375 & 10.45 & 7.324 & 2.15 \\
& supplement & & & & & \\
& (glucose g/l) & & & & & \\
\hline
\end{tabular}

TABLE 5 | Main effects of selected factors on carbohydrates production.

\begin{tabular}{lllllll}
\hline S. no. & Factor & Level 1 & Level 2 & Level 3 & Level 4 & L2 - L1 \\
\hline 1 & $\mathrm{pH}$ & 1.185 & 0.812 & 1.12 & 1.11 & -0.373 \\
2 & $\begin{array}{l}\text { Salinity } \\
(\mathrm{NaCl} \text { g/l) }\end{array}$ & 1.087 & 0.982 & 1.207 & 0.947 & -0.102 \\
3 & $\begin{array}{l}\text { Temperature } \\
\left({ }^{\circ} \mathrm{C}\right)\end{array}$ & 1.587 & 0.3 & 2.029 & 0.31 & -1.297 \\
4 & $\begin{array}{l}\text { Carbon } \\
\text { supplement } \\
\text { (glucose g/l) }\end{array}$ & 0.98 & 0.839 & 1.264 & 1.142 & -0.142 \\
& & & & & \\
\hline
\end{tabular}

effect on the total lipid synthesis, while temperature showed the least influence $(\mathrm{pH}>$ carbon supplementation $>$ salinity $>$ temperature). On the contrary, salinity showed a stronger effect on the neutral lipids synthesis, while $\mathrm{pH}$ showed least influence ( salinity $>$ temperature $>$ carbon supplementation $>\mathrm{pH}$ ).

The effect of $\mathrm{pH}$ on the total lipid synthesis was significant. Acidic redox microenvironment ( $\mathrm{pH}$ 6) illustrated higher lipid synthesis. The favorable $\mathrm{pH}$ range for microalgae cultivation varies between 6 and 9, depending on the metabolic mode of cultivation and strain used. Heterotrophic mode cultivation between pH 6 and 7 was reported to be optimum (Kumar et al., 2010). The $\mathrm{CO}_{2}$ /organic carbon uptake by algae associates with an increase in biomass yield but leads to a decrease in $\mathrm{pH}$ that affects the microalgae physiology toward lipid synthesis (Belkin and Boussiba, 1991). Experiment no. 6 (pH 6, 30 g COD/l, 2 g NaCl/l, and $20^{\circ} \mathrm{C}$ ) documented relatively higher lipid (total) productivity (55\% of DCW; $21.62 \mathrm{mg} / \mathrm{l} /$ day) (Figure 1A). During cultivation of microalgae, the decrement in the $\mathrm{pH}$ from 6 to 4.8 was noticed. Acidic $\mathrm{pH}$ facilitates the diffusion of protons required for activation of hexose/proton symporter system for transport of glucose molecules from ambient cell surface to internal cytoplasm to take part in glycolysis pathway and subsequent lipid synthesis (Morales-Sánchez et al., 2013). With this experimental condition, protein and carbohydrates concentrations of $9.4 \mathrm{mg} / \mathrm{ml}$ and $146 \mathrm{mg} / \mathrm{g}$ DCW were observed, respectively. Subsequent to $\mathrm{pH}$, carbon concentration (glucose) showed significant control on the 

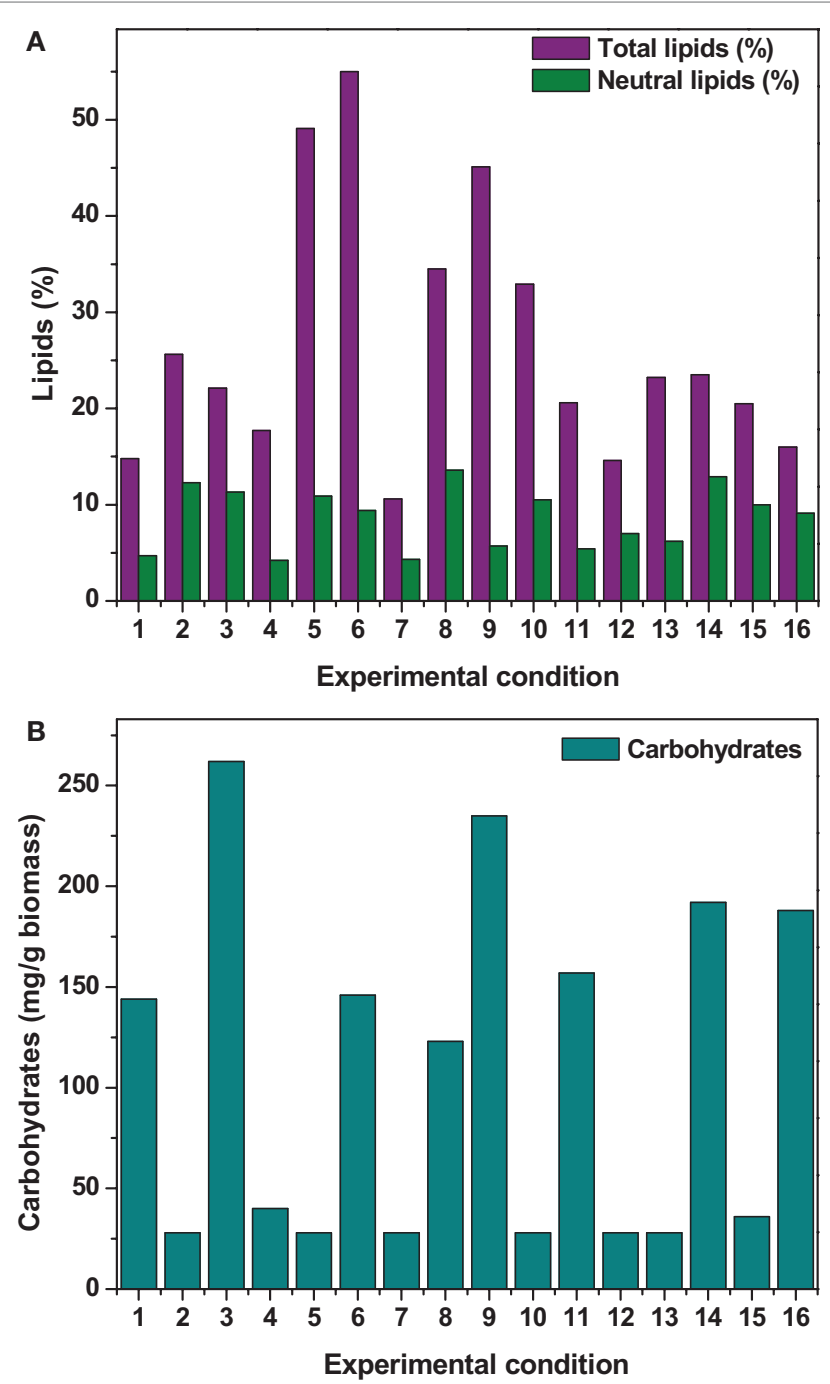

FIGURE 1 | (A) Total lipid and neutral lipid (B) carbohydrates concentration obtained from all the experimental conditions.

total lipid synthesis. Carbon in the form of glucose influenced the lipid accumulation (up to certain concentration). Glucose loading of $30 \mathrm{~g} / \mathrm{l}$ at level 4 showed higher lipid productivity $(55 \%$ of DCW; Exp no. 6). Carbon at optimal concentration during the SP increased the metabolic rate, manifesting glycolysis which also might influence the lipid synthesis (Chandra et al., 2014). Maximum biomass productivity $(39.37 \mathrm{mg} / \mathrm{l} /$ day) with COD removal efficiency of $66 \%$ was observed with this experimental variation. Glucose absorption consumes less energy compared to $\mathrm{CO}_{2}$ uptake by photosynthesis (Garcia et al., 2011). TC concentration $[9.19 \mu \mathrm{g} / \mathrm{ml}(\operatorname{chl} a, 6.61 \mu \mathrm{g} / \mathrm{ml}$; chl $b, 2.58 \mu \mathrm{g} / \mathrm{ml})]$ also correlated with the biomass production.

Contrary to the total lipids, salinity (5 g/l NaCl) showed marked effect on the neutral lipids production [13.6\% of DCW (total, 36\% of DCW)] as documented with Exp no. 8 (1 g COD/l; $\mathrm{pH} 6 ; 30^{\circ} \mathrm{C}$ ). Salinity-induced stress influences both physiological and biochemical mechanisms associated with the lipid synthesis (Kalita et al., 2011). Exposure of microalgae to hyper saline conditions alter their metabolism to uptake and export ions through the cell membrane, and the resulting stress proteins accumulated facilitates increment in the lipids content to adapt to the extreme environment (Talebi et al., 2013). Lipid induction phase operated under salt stress showed production of higher number of saturated fatty acid (SFA) methyl esters with the improved fuel properties along with increased lipid production (Venkata Mohan and Devi, 2014). The temperature at level $1\left(20^{\circ} \mathrm{C}\right)$ and level 3 $\left(30^{\circ} \mathrm{C}\right)$ showed favorable lipid synthesis. Cultivation at $30^{\circ} \mathrm{C}$ registered noticeable improvement in the lipid production, especially neutral lipids. The change in the cultivation temperature from optimal range invariably effects the composition of membrane lipids to maintain the normal function of microalgae (Subhash et al., 2014). With Exp no. 8, the $\mathrm{pH}$ increased from 6 to 7.1 during cultivation with COD removal efficiency of $86.2 \%$ and biomass productivity of $11.43 \mathrm{mg} / \mathrm{l} /$ day, were neutral lipid productivity of $3.88 \mathrm{mg} / \mathrm{l} /$ day [TC, $8.13 \mu \mathrm{g} / \mathrm{ml}(\mathrm{Chl} a / C h l b, 5.61 / 2.51 \mu \mathrm{g} / \mathrm{ml})$ ]. The protein and carbohydrates concentration was found to be $7.68 \mathrm{mg} / \mathrm{ml}$ and $106 \mathrm{mg} / \mathrm{g}$ DCW, respectively.

\section{Lipids Profile}

The increase in cultivation temperature resulted in increased distribution of lipids in the form of SFAs (Boussiba et al., 1987). Temperature-induced stress showed influence on increment in the neutral lipid content illustrating feasibility toward good biodiesel properties with higher SFAs to unsaturated fatty acids (USFA) ratio (Subhash et al., 2014). Similar trend was observed in the present experiment with the presence of stearic (C18:0) and palmitic (C16:0) acids (Figure 2). The presence of long-chain fatty acids from C12:0 to C20:0 were observed in the Exp no. 8 due to the combined effect of salinity and temperature. The concentrations of SFAs were high with palmitic acid (C16:0) (50.8\%), margaric acid (C17:0) (2.1\%), and stearic acid (C18:0) (10.1\%) compared to USFA [linoleic acid (C18:2) (6.8\%); linolenic acid (C18:3) (2.8\%)]. Fatty acids, including palmitic (40.7\%) and myristic acids (4.2\%), are known to have potential antibacterial and antifungal activities. Modification of fatty acids composition is one of the mechanisms used by algae to regulate osmotic balance and maintain membrane fluidity under the altered conditions (Adams et al., 2013). Low temperature induces the synthesis of more USFA to speed up the lipids desaturation as a recompensation measure to maintain the cell membrane fluidity (Perez-Garcia et al., 2011). Operating at lower temperature gives rise to more intracellular molecular oxygen and consequently improves the activities of desaturases and elongases that are involved in the biosynthesis of USFA (Chen and Chen, 2006). The presence of long-chain fatty acids from C12:0 to C24:0 were also observed due to the combined effect of $\mathrm{pH}$ and high carbon content.

\section{Factor Influence on Carbohydrates Accumulation}

Among the studied stress factors, temperature showed marked effect on the carbohydrate accretion, while salinity showed the least influence (temperature $>\mathrm{pH}>$ carbon supplementation $>$ salinity). Nutrient limitation facilitates the accumulation of carbohydrates due to distinct reduction in cell growth (Ball et al., 1990). Temperature at level $3\left(30^{\circ} \mathrm{C}\right)$ showed high carbohydrate accretion (262 mg/g biomass; Exp no. 3; 4 pH, 2 g 


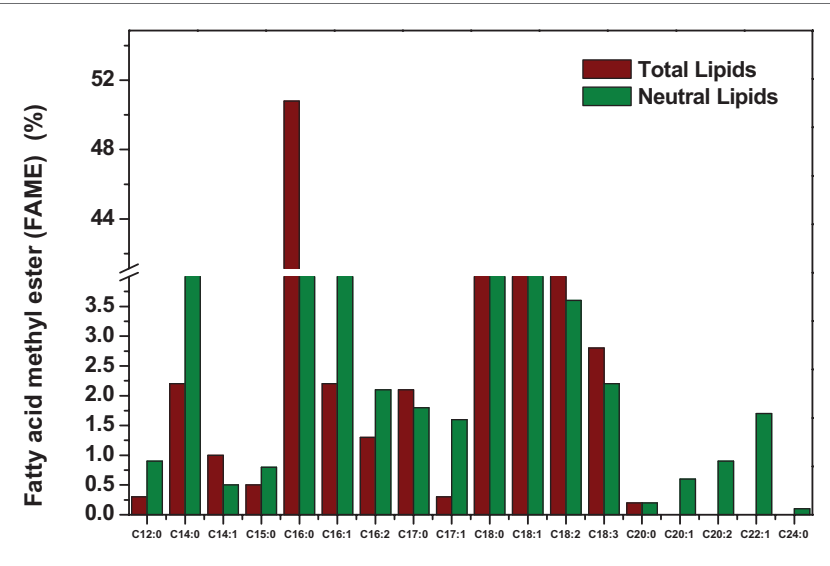

FIGURE 2 | Fatty acid methyl ester (FAME) composition of experimental condition six (TL) and eighth (NL)

$\mathrm{NaCl} / \mathrm{l} ; 15 \mathrm{~g} \mathrm{COD} / \mathrm{l})$ than level $1\left(20^{\circ} \mathrm{C}\right)$, level $2\left(25^{\circ} \mathrm{C}\right)$, and level $4\left(35^{\circ} \mathrm{C}\right)$ (Table 2; Figure 1B). Next to the temperature, carbon load (level 3; $15 \mathrm{~g} \mathrm{COD/1)} \mathrm{showed} \mathrm{feasibility} \mathrm{to} \mathrm{higher} \mathrm{accretion}$ of carbohydrate with substrate degradation of $66 \%$. Carbohydrate accumulation improves by increasing the carbon load during the SP of microalgae cultivation (Giordano, 2001; Xia and Gao, 2005; Chandra et al., 2014). Under nutrient limiting conditions and with good supply of carbon, the protein content of microalgae function as nitrogen source, and the carbohydrate content may increase considerably (Ball et al., 1990). Salinity at level 3 (2 g/l $\mathrm{NaCl}$ ) showed good carbohydrates accumulation. Accumulation of carbohydrates takes place as a response to an immediate $\mathrm{NaCl}$ shock (Zheng et al., 1997). Salt stress facilitates production of reactive oxygen species, which inhibit RuBisCO activity and lead to photoinhibition that concurrently decreases the biomass growth (Neale and Melis, 1989; Murata et al., 2007). High NaCl concentration also inactivates the ATP-synthase resulting protein synthesis inhibition in microalgae (Allakhverdiev et al., 2005). With Exp no. 3, the $\mathrm{pH}$ varied marginally from 4 to 3.9 during cultivation with COD removal efficiency of $66 \%$ and biomass productivity of $19.0 \mathrm{mg} / \mathrm{l} /$ day [TC, $7.3 \mu \mathrm{g} / \mathrm{ml}$ (Chl a/Chl b, $5.61 / 1.69 \mu \mathrm{g} / \mathrm{ml})]$. The protein concentration was found to be $10.71 \mathrm{mg} / \mathrm{ml}$.

Maximum substrate degradation (based on COD removal efficiency) of 66,86 , and $66 \%$ was observed at the end of SP in experiments 6, 8, and 3, respectively. Apart from the lipid synthesis, the substrate utilized by the microalgae also associates with the biomass/carbohydrate production $(6.37 / 146,1.83 / 123$, and $3.9 / 262 \mathrm{~g} / \mathrm{l} / \mathrm{mg} / \mathrm{g}$ ) during the heterotrophic microalgae cultivation under starvation phase. Maximum chlorophyll concentration was observed at the end of the starvation phase (Exp no. 6: $9.19 \mu \mathrm{g} / \mathrm{ml}$; Exp no. 8: $10.9 \mu \mathrm{g} / \mathrm{ml}$; Exp no. 3: $7.3 \mu \mathrm{g} / \mathrm{ml})$ along with good protein concentration (Exp no. 6: $9.46 \mathrm{mg} / \mathrm{ml}$; Exp no. 8: $7.68 \mathrm{mg} / \mathrm{ml}$; Exp no. 3: $10.71 \mathrm{mg} / \mathrm{ml})$.

\section{Factor Interactions}

Evaluating factors' interaction facilitates understanding the complexity of the process. The estimated interactions based on the
TABLE 6 | Automated test for presence of interaction factors.

\begin{tabular}{llcccc}
\hline S. no. & $\begin{array}{l}\text { Interacting factor } \\
\text { pairs (based on SI) }\end{array}$ & Columns & $\begin{array}{c}\text { SI } \\
(\%)\end{array}$ & $\begin{array}{c}\text { Reserved } \\
\text { column }\end{array}$ & $\begin{array}{c}\text { Optimum } \\
\text { levels }\end{array}$ \\
\hline 1 & $\begin{array}{l}\text { Salinity }(\mathrm{NaCl}) \times \\
\text { temperature }\left({ }^{\circ} \mathrm{C}\right)\end{array}$ & $2 \times 3$ & 71.73 & 1 & {$[2,1]$} \\
2 & $\begin{array}{l}\mathrm{pH} \times \text { temperature }\left({ }^{\circ} \mathrm{C}\right) \\
\mathrm{pH} \times \text { carbon }\end{array}$ & $1 \times 3$ & 18.8 & 2 & {$[2,1]$} \\
3 & $\begin{array}{l}\text { supplement } \\
\text { Salinity }(\mathrm{NaCl}) \times \text { carbon }\end{array}$ & $2 \times 4$ & 7.09 & 6 & {$[2,4]$} \\
4 & $\begin{array}{l}\text { supplement } \\
\text { Temperature }\left({ }^{\circ} \mathrm{C}\right) \times\end{array}$ & $3 \times 4$ & 5.85 & 7 & {$[1,4]$} \\
5 & $\begin{array}{l}\text { carbon supplement } \\
\text { pH } \times \text { salinity }(\mathrm{NaCl})\end{array}$ & $1 \times 2$ & 5.51 & 3 & {$[2,2]$} \\
\hline
\end{tabular}

severity index (SI) help to know the influence of two individual factors at various levels (Table 6). Salinity with temperature showed highest SI (71.73\%), followed by $\mathrm{pH}$ and temperature (18.8\%), pH and carbon supplementation (14.75\%) (Figure 3). Temperature showed high level of interaction with $\mathrm{pH}(71 \%)$. The interaction between carbon and temperature (SI, 5.8\%) showed a marginal influence on carbohydrate production. Interaction between salinity and $\mathrm{pH}$ (SI, 5.5\%) has no significant influence on lipid and carbohydrate production.

\section{Analysis of Variance}

It is evident from ANOVA that all the factors and interactions considered in the experimental design had statistically significant at $95 \%$ confidence limit ( $F$-ratios). The experimental degree of freedom (DOF) is 15 (factors-DOF, 3) (Tables 7-9). Salinity had the maximum contribution $(29.12 \%)$ on total lipid production, followed by $\mathrm{pH}(27.97 \%)$ and carbon supplementation (27.49\%) at the individual level (Table 7) (Figure 3A). The temperature had minimal impact on the lipid synthesis (6.33\%). On the whole, salinity, $\mathrm{pH}$, and carbon supplementation at their individual levels contributed over $95 \%$ of the influence on the lipid production, indicating that these factors play crucial role on lipid synthesis. The temperature had the maximum contribution $(32.82 \%)$ on neutral lipid synthesis at the individual level, followed by salinity (23.08\%) and carbon supplementation (14.56\%) (Table 8) (Figure 3B). $\mathrm{pH}$ showed minimal impact on the production process $(5.84 \%)$. Overall, temperature, salinity, carbon supplementation, and $\mathrm{pH}$ at their individual levels contributed over $76.3 \%$ of the influenced factors in an escalation of neutral lipid synthesis. The temperature showed maximum contribution (85.25\%), followed by carbon supplementation on carbohydrate accumulation at the individual level (Table 9) (Figure 3C). On the whole, temperature and carbon supplementation at their individual levels contributed over $86.013 \%$ of the influence on carbohydrates production.

\section{Optimum Conditions for Maximum Productivity}

Optimum conditions during SP of operation to achieve higher lipid (total) productivity from microalgae by the selected factors contribution is shown in Table 10. The optimum operating conditions 
A

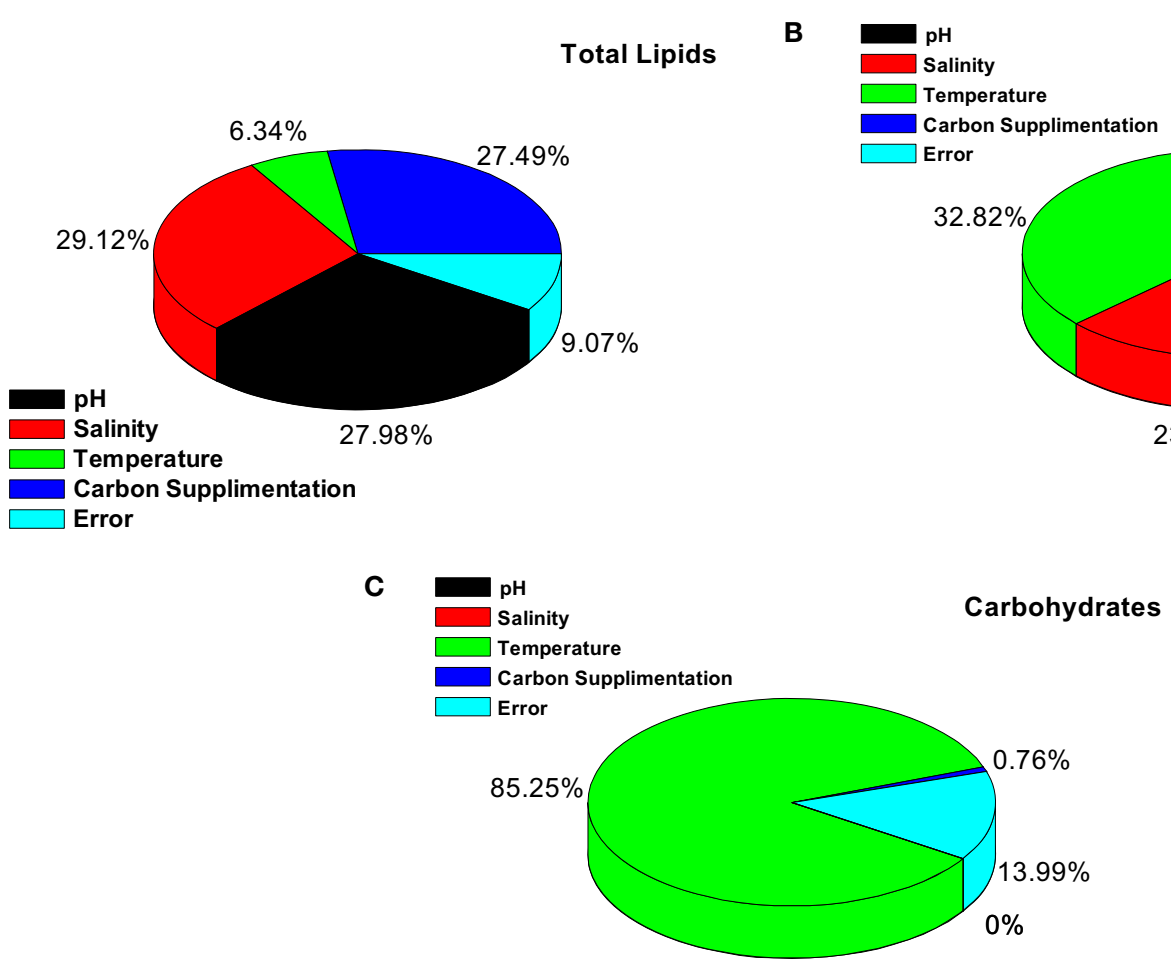

FIGURE 3 | Significant factor and interaction influence on the output of (A) total lipids, (B) neutral lipids and (C) carbohydrates.

TABLE 7 | Analysis of variance (ANOVA) for total lipids production.

\begin{tabular}{|c|c|c|c|c|c|c|c|}
\hline S. no. & Factor & DOF & Sum of squares & Variance & $F$-ratio & Pure sum & Percent \\
\hline 2 & Salinity ( $\mathrm{NaCl} \mathrm{g} / \mathrm{l})$ & 3 & 805.427 & 268.475 & 17.046 & 758.177 & 29.12 \\
\hline 3 & Temperature $\left({ }^{\circ} \mathrm{C}\right)$ & 3 & 212.247 & 70.749 & 4.492 & 164.997 & 6.337 \\
\hline \multirow{2}{*}{4} & Other/error & 3 & 47.249 & 15.749 & & & 9.075 \\
\hline & Total & 15 & 2603.597 & & & & 100 \\
\hline
\end{tabular}

TABLE 8 | Analysis of variance analysis (ANOVA) for neutral lipids synthesis.

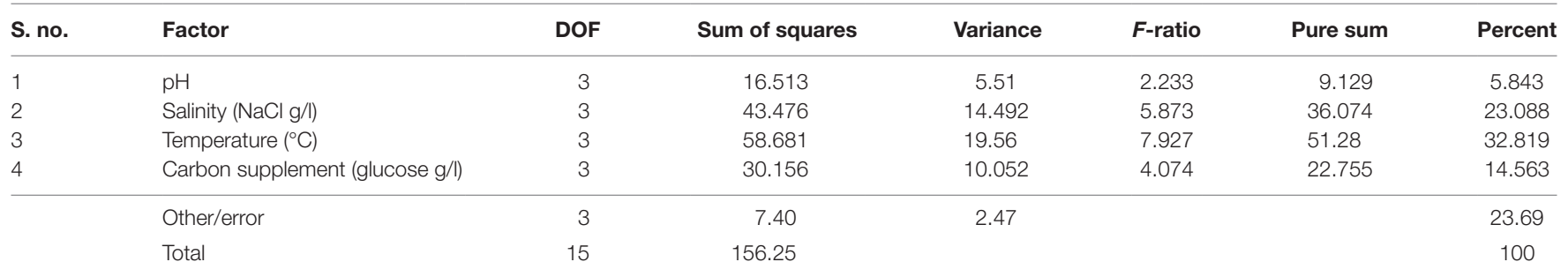

TABLE 9 | Analysis of variance (ANOVA) for carbohydrates production.

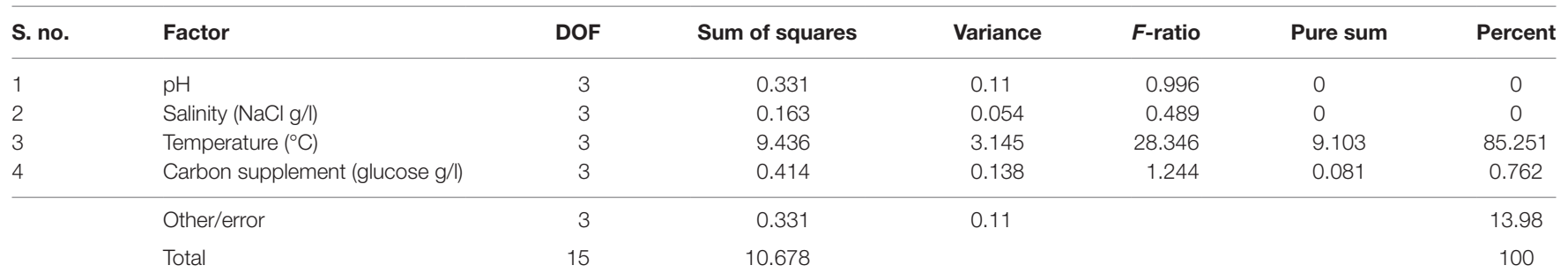



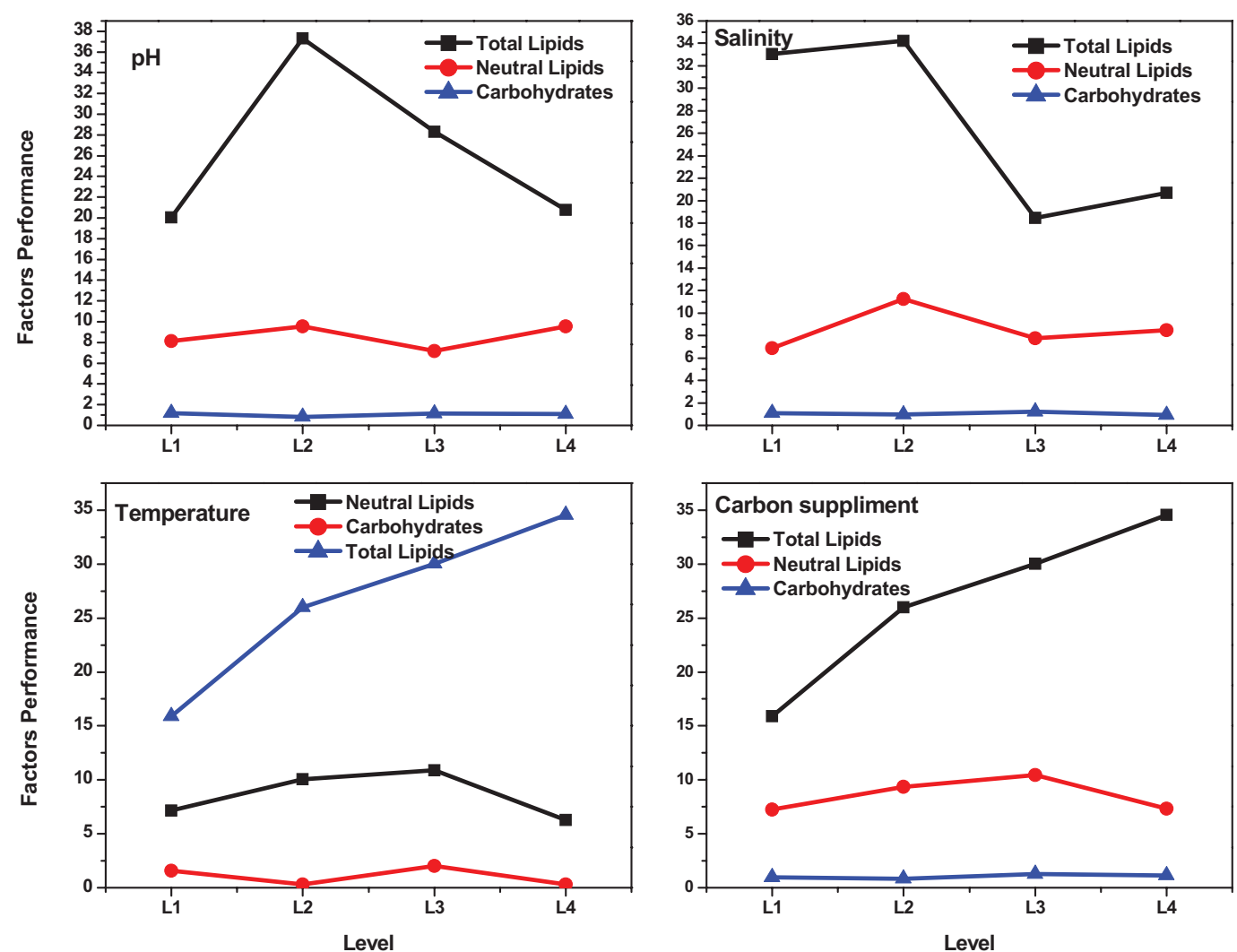

FIGURE 4 | Individual factors performance at different levels

TABLE 10 | Optimum conditions and their contribution on total lipids.

\begin{tabular}{llccc}
\hline S. no. & Factor & Level description & Level & Contribution \\
\hline 1 & $\mathrm{pH}$ & 6 & 2 & 10.687 \\
2 & Salinity $(\mathrm{NaCl} \mathrm{g/l)}$ & 1 & 2 & 7.637 \\
3 & Temperature $\left({ }^{\circ} \mathrm{C}\right)$ & 30 & 3 & 4.687 \\
4 & Carbon supplement & 30 & 4 & 7.962 \\
& (glucose g/l) & & &
\end{tabular}

Total contribution from all factors

30.97

Current grand average of performance

26.61

Expected result at optimum condition

57.58

showed the requirement of acidic microenvironment ( $\mathrm{pH}$ 6) with $1 \mathrm{~g} \mathrm{NaCl} / 1,20^{\circ} \mathrm{C}$, and $30 \mathrm{~g} \mathrm{COD} / \mathrm{l}$, which resulted in the increment of lipid (total) production from 14.6 to $57.6 \%$ (from 26.6\%) (Figure 4). A total contribution of factors at optimized conditions was $30.97 \%$ for lipid production with a maximum contribution of $10.68 \%$ from $\mathrm{pH}$. Salinity was specifically found to be the most significant factor influencing neutral lipid production (Table 11). The optimum operating conditions showed the requirement of acidic microenvironment ( $\mathrm{pH}$ 6) with $1 \mathrm{~g} \mathrm{NaCl} / \mathrm{l}, 30^{\circ} \mathrm{C}$, and $15 \mathrm{~g}$ $\mathrm{COD} / \mathrm{l}$, which resulted in the increment of neutral lipid from $8.6 \%$ to $16.4 \%$ (Figure 4 ). The temperature was found to be the most important factor influencing carbohydrate production (Table 12).
TABLE 11 | Optimum conditions and their contribution on neutral lipids.

\begin{tabular}{llccc} 
S. no. & Factor & Level description & Level & Contribution \\
\hline 1 & $\mathrm{pH}$ & 6 & 2 & 0.956 \\
2 & Salinity $(\mathrm{NaCl} \mathrm{g} / \mathrm{l})$ & 1 & 2 & 2.681 \\
3 & Temperature $\left({ }^{\circ} \mathrm{C}\right)$ & 30 & 3 & 2.281 \\
4 & Carbon supplement & 15 & 3 & 1.856 \\
& (glucose g/l) & & 7.77 \\
\hline \multicolumn{2}{l}{ Total contribution from all factors } \\
Current grand average of performance & & 8.59 \\
Expected result at optimum condition & & 16.36 \\
\hline
\end{tabular}

TABLE 12 | Optimum conditions and their contribution on carbohydrates.

\begin{tabular}{llccc}
\hline S. no. & Factor & Level description & Level & Contribution \\
\hline 1 & $\mathrm{pH}$ & 4 & 1 & 0.128 \\
2 & Salinity $(\mathrm{NaCl} \mathrm{g/l)}$ & 2 & 3 & 0.15 \\
3 & Temperature $\left({ }^{\circ} \mathrm{C}\right)$ & 30 & 3 & 0.973 \\
4 & Carbon supplement & 15 & 3 & 0.208 \\
& (glucose $\mathrm{g} / \mathrm{l})$ & & & \\
\hline
\end{tabular}

Total contribution from all factors

145.9

Current grand average of performance

105.6

Expected result at optimum condition 
The favorable operating conditions showed the requirement of acidic microenvironment ( $\mathrm{pH} 4$ ) with $2 \mathrm{~g} \mathrm{NaCl} / \mathrm{l}, 30^{\circ} \mathrm{C}$, and $15 \mathrm{~g} \mathrm{COD} / 1$ results in the increment of carbohydrate production from 140 to $251.5 \mathrm{mg} / \mathrm{g}$ biomass (Figure 4). Carbohydrate profile showed the presence of $35 \%$ of xylose and $20 \%$ of arabinose.

\section{DISCUSSION}

Data envelopment analysis (DEA) technique was used to analyze the relative performance of the system based on the output parameters viz., lipid productivity (total and neutral) and carbohydrates production. DEA offers an easy approach to measure, compare the performance, and analyze the results obtained by interpreting the output of a given system based on the relative efficiency (not on absolute efficiency) using graphical approach (Venkata Mohan et al., 2008). The relative efficiency of any given system indicates the extent to which other systems can improve its performance. Total and neutral productivity and carbohydrates production were considered as three output parameters corresponding to input parameter ( $\mathrm{pH}$ ) (Table 13; Figure 5). The relative efficiency of the system can be calculated by comparing the current performance of the system to the best possible performance that the system could be reasonably expected to achieve as per the Eq. 1, where, $X$ represents the length of the line from the origin to the point obtained by plotting two ratios of the system and $Y$ denotes length of the line from the origin through the point obtained by the system to the efficient frontier.

$$
\text { Relative efficiency }=[(X / Y) \times 100]
$$

Experiment 6 (carbon concentration $30 \mathrm{~g} / \mathrm{l}$; temperature $20^{\circ} \mathrm{C}$; salinity $1 \mathrm{~g} / \mathrm{l}$; pH 6), experiment 3 (carbon concentration $15 \mathrm{~g} / \mathrm{l}$; temperature $30^{\circ} \mathrm{C}$; salinity $2 \mathrm{~g} / \mathrm{l} ; \mathrm{pH} 4$ ) and experiment 2 (carbon concentration $1 \mathrm{~g} / \mathrm{l}$; temperature $25^{\circ} \mathrm{C}$; salinity $1 \mathrm{~g} / \mathrm{l}$; $\mathrm{pH} 4$ ) yielded maximum efficiency (100\%) among the experimental variations studied with respect to total lipids, neutral lipids and carbohydrates productivities. In all the three cases of data analyses by DEA considering $\mathrm{pH}$ as input, experimental points on the efficient frontier lines (relative efficiency 100\%) illustrated the efficacy of acidophilic $\mathrm{pH}(6-4)$ with salinity ( 1 or $2 \mathrm{~g} / \mathrm{l}$ ), carbon supplemented with high glucose concentration and temperature in the range of $20-30^{\circ} \mathrm{C}$. About six of the experimental variations studied are above $60 \%$ of the relative efficiency. Experiments above $96 \%$ relative efficiency showed positive influence of acidophilic cultivation.

TABLE 13 | Consolidated data of DEA analysis.

\begin{tabular}{lllll}
\hline \multicolumn{2}{c}{ TL vs NL } & & \multicolumn{2}{c}{ TL vs Carbohydrates } \\
\cline { 5 - 5 } $\begin{array}{l}\text { Experiment } \\
\text { number }\end{array}$ & $\begin{array}{l}\text { Relative } \\
\text { efficiency (\%) }\end{array}$ & & $\begin{array}{l}\text { Experiment } \\
\text { number }\end{array}$ & $\begin{array}{l}\text { Relative } \\
\text { efficiency (\%) }\end{array}$ \\
\hline 6 & 100 & & 6 & 100 \\
2 & 100 & 3 & 100 \\
5 & 96.8 & 2 & 90.1 \\
3 & 91.0 & 5 & 71.9 \\
8 & 82.1 & 9 & 70.6 \\
9 & 62.5 & & 8 & 66.1
\end{tabular}

As shown in Table 14, microalgae cultivation at $\mathrm{pH} 6$ increased lipid productivity with more number of SFAs in both experiments 6 and 8. Influence of salinity was observed markedly on increment in palmitic acid (C16:0) fraction. Microalgae can survive in extreme microenvironments; a minor shift in $\mathrm{pH}$ in external environment can change their metabolic activity (Varshney et al., 2015). A change in acidophilic environment from $\mathrm{pH} 6$ to 4 , microalgae showed transition of biochemical pathway from lipid to carbohydrates synthesis when experimental conditions $6 / 8$ and 3 were compared. Studies also reveal that at acidophilic conditions showed increased basal level of heat shock protein (HSP), higher levels of the antioxidative enzymes, ascorbate peroxidase (APX) and which is thought to be an adaptive mechanism to extreme acidic environment (Gerloff-Elias et al., 2006; Garbayo et al., 2007). The acidophiles also showed increased production of the antioxidants lutein and $\beta$-carotene, respectively (Garbayo et al.,
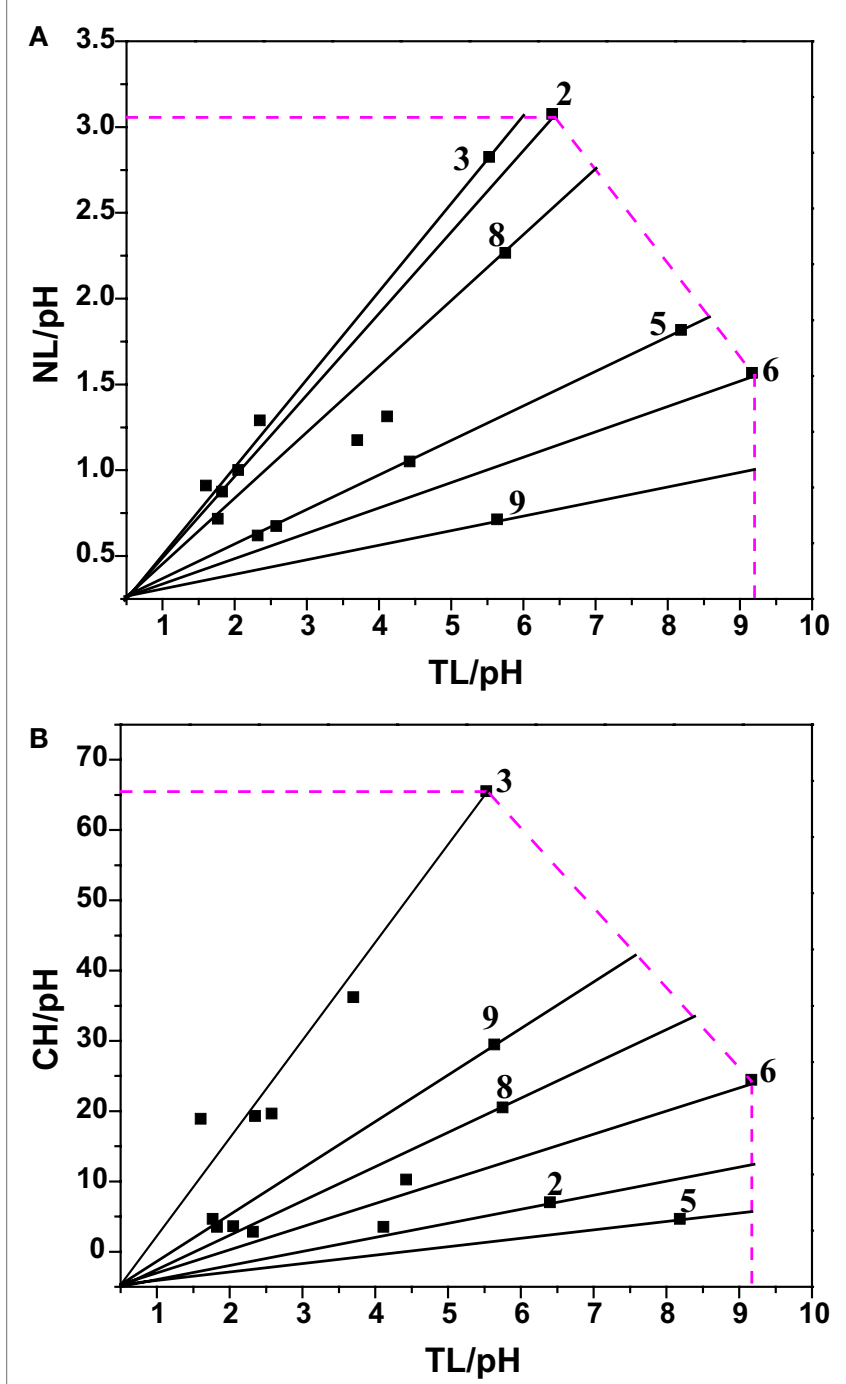

FIGURE 5 | Experimental data expressed in DEA format to calculate the relative efficiency $[(A)$ Neutral Lipids (NL) rate and Total Lipids (TL) vis a vis $\mathrm{pH}$; $(\mathrm{B})$ Carbohydrate $(\mathrm{CH})$ and Total Lipid $(\mathrm{TL})$ vis a vis $\mathrm{pH}$. 
TABLE 14 | Consolidate optimum conditions toward biomass and lipid production obtained from the study.

\begin{tabular}{|c|c|c|c|c|c|c|c|c|c|c|c|}
\hline \multirow{2}{*}{$\begin{array}{l}\text { Experiment } \\
\text { number }\end{array}$} & \multicolumn{4}{|c|}{ Experimental condition } & \multirow{2}{*}{$\begin{array}{l}\text { Total/neutral } \\
\text { lipids (\% DCW) }\end{array}$} & \multirow{2}{*}{$\begin{array}{l}\text { Biomass } \\
\text { production } \\
(\mathrm{g} / \mathrm{l})\end{array}$} & \multirow{2}{*}{$\begin{array}{l}\text { Lipid } \\
\text { productivity } \\
\text { (mg/l/day) }\end{array}$} & \multirow[t]{2}{*}{ SFAs } & \multicolumn{2}{|l|}{ UFAs } & \multirow{2}{*}{$\begin{array}{l}\text { Carbohydrates } \\
\text { (mg/g biomass }\end{array}$} \\
\hline & $\mathrm{pH}$ & $\begin{array}{l}\text { Salinity } \\
(\mathrm{g} / \mathrm{l})\end{array}$ & $\begin{array}{l}\text { Temperature } \\
\left({ }^{\circ} \mathrm{C}\right)\end{array}$ & $\begin{array}{l}\text { Carbon } \\
\text { supp (g/l) }\end{array}$ & & & & & MUFA & PUFA & \\
\hline $\begin{array}{l}\text { Experiment } \\
\text { No. } 6\end{array}$ & 6 & 1 & 20 & 30 & $55.0 / 9.4$ & 6.3 & 21.62 & $\begin{array}{l}7 \text { No. } \\
\text { (C16:0; } \\
\text { 40.7\%) }\end{array}$ & $\begin{array}{l}5 \text { No. } \\
\text { (C18:1; } \\
21.4 \%)\end{array}$ & $\begin{array}{l}4 \text { No. } \\
\text { (C18:2; } \\
3.6 \%)\end{array}$ & 146 \\
\hline $\begin{array}{l}\text { Experiment } \\
\text { No. } 8\end{array}$ & 6 & 5 & 30 & 1 & $34.5 / 13.6$ & 1.8 & 3.88 & $\begin{array}{l}6 \text { No. } \\
\text { (C16:0; } \\
50.8 \% \text { ) }\end{array}$ & $\begin{array}{l}3 \text { No. } \\
\text { (C18:1; } \\
19.4 \%)\end{array}$ & $\begin{array}{l}3 \text { No. } \\
\text { (C18:2; } \\
6.8 \%)\end{array}$ & 123 \\
\hline Experiment No. 3 & 4 & 2 & 30 & 15 & $22.1 / 11.3$ & 3.9 & 4.21 & & & & 262 \\
\hline $\begin{array}{l}\text { Total lipids } \\
\text { (Table 10) }^{\mathrm{a}}\end{array}$ & 6 & 1 & 30 & 30 & 57.5 & & & & & & 251 \\
\hline $\begin{array}{l}\text { Neutral lipids } \\
\text { (Table 11) }^{a}\end{array}$ & 6 & 1 & 30 & 15 & 16.3 & & & & & & \\
\hline $\begin{array}{l}\text { Carbohydrates } \\
\text { (Table 12) }^{\mathrm{a}}\end{array}$ & 4 & 2 & 30 & 15 & & & & & & & \\
\hline
\end{tabular}

aptimum condition.

2008; Vaquero et al., 2012). Increase in carbon concentration and salinity favored high number of mono unsaturated fatty acids (MUFA). In experiment No. 6, more number of polyunsaturated fatty acids (PUFAs; structural lipids) with major fractions of oleic acid (C18:1) and linoleic acid (C18:2) was observed, which basically contributes to the high biomass productivity. Higher lipid fraction (55\% of DCW) and biomass productivity $(39.3 \mathrm{mg} / \mathrm{l} /$ day) were obtained with high carbon, minimal salinity, and low temperature conditions (Experiment No. 6).

\section{CONCLUSION}

Design of experimental methodology based on Taguchi approach illustrated the specific function of selected factors on microalgae lipid synthesis and carbohydrate production during stressinduced heterotrophic cultivation. Among the four factors, $\mathrm{pH}$, salinity, and carbon concentration showed significant influence on the lipid synthesis. This study reported a high total lipids concentration (55\% of DCW; $21.6 \mathrm{mg} / \mathrm{l} /$ day), observed in high carbon, minimal salinity, and low temperature conditions. A maximum neutral lipids concentration (13.6\% of DCW; $3.8 \mathrm{mg} / \mathrm{l} /$ day) was observed in high salinity, low carbon conditions at

\section{REFERENCES}

Adams, C., Godfrey, V., Wahlen, B., Seefeldt, L., and Bugbee, B. (2013). Understanding precision nitrogen stress to optimize the growth and lipid content tradeoff in oleaginous green microalgae. Bioresour. Technol. 131, 188-194. doi:10.1016/j.biortech.2012.12.143

Allakhverdiev, S. I., Nishiyama, Y., Takahashi, S., Miyairi, S., Suzuki, I., and Murata, N. (2005). Systematic analysis of the relation of electron transport and ATP synthesis to the photodamage and repair of photosystem II in Synechocystis. Plant Physiol. 137, 263-273. doi:10.1104/pp.104.054478

APHA. (1998). Standard Methods for the Examination of Water and Wastewater, 20th Edn. Washington, DC: American Public Health Association/American Water Works Association/Water Environment Federation.

Ball, S. G., Dirick, L., Decq, A., Martiat, J. C., and Matagne, R. F. (1990). Physiology of starch storage in the monocellular alga Chlamydomonas reinhardtii. Plant Sci. 66, 1-9. doi:10.1016/0168-9452(90)90162-H acidophilic microenvironment. Acidophilic microenvironment, moderate salinity, and high carbon concentration illustrated significant influence on the carbohydrates synthesis. The FAME analysis documented good biodiesel properties with a higher number of SFAs, especially palmitic acid (C16:0) followed by MUFA and PUFA with major fractions of oleic acid (C18:1) and linoleic acid (C18:2). The study documented feasibility of heterotrophic mode of microalgae cultivation toward regulating higher lipid productivity, along with waste treatment.

\section{AUTHOR CONTRIBUTIONS}

All the authors have equally contributed to the manuscript and mutually agreed for submission of the work.

\section{ACKNOWLEDGMENTS}

The authors wish to thank Director, Council for Scientific and Industrial Research (CSIR)-IICT, Hyderabad, for encouragement. Authors acknowledge funding from CSIR in the form of Network project - BioEn (CSC-0116). PC acknowledges CSIR for providing research fellowship.

Belkin, S., and Boussiba, S. (1991). Resistance of spirulina platensis to ammonia at high pH values. Plant Cell Physiol. 32, 953-958.

Boussiba, S., Vonshak, A., Cohen, Z., Avissar, Y., and Richmond, A. (1987). Lipid and biomass production by the halotolerant microalga Nannochloropsis salina. Biomass 12, 37-47. doi:10.1016/0144-4565(87)90006-0

Brennan, L., and Owende, P. (2010). Biofuels from microalgae - a review of technologies for production, processing, and extractions of biofuels and co-products. Renew. Sustain. Energ. Rev. 14, 557-577. doi:10.1016/j.rser.2009.10.009

Chandra, R., Rohit, M. V., Swamy, Y. V., and Venkata Mohan, S. (2014). Regulatory function of organic carbon supplementation on biodiesel production during growth and nutrient stress phases of mixotrophic microalgae cultivation. Bioresour. Technol. 165, 279-287. doi:10.1016/j.biortech.2014.02.102

Chen, G. Q., and Chen, F. (2006). Growing phototrophic cells without light. Biotechnol. Lett. 28, 607-616. doi:10.1007/s10529-006-0025-4

Chen, M., Tang, H., Ma, H., Holland, T. C., Ng, K. Y., and Salley, S. O. (2011). Effect of nutrients on growth and lipid accumulation in the green algae 
Dunaliella tertiolecta. Bioresour. Technol. 102, 1649-1655. doi:10.1016/j. biortech.2010.09.062

Chiranjeevi, P., and Venkata Mohan, S. (2016). Critical parametric influence on microalgae cultivation towards maximizing biomass growth with simultaneous lipid productivity. Renew. Energy. doi:10.1016/j.renene.2016.03.063

Cong, L., and Lu-Kwang, J. (2014). Conversion of wastewater organics into biodiesel feedstock through the predator-prey interactions between phagotrophic microalgae and bacteria. RSC Adv. 4, 44026-44029. doi:10.1039/C4RA06374K

Cong, L., Suo, X., and Lu-Kwang, J. (2016). Cultivation of phagotrophic algae with waste activated sludge as a fast approach to reclaim waste organics. Water. Res 91, 195-202. doi:10.1016/j.watres.2016.01.021

Dayananda, C., Sarada, R., Usha Rani, M., Shamala, T. R., and Ravishankar, G. A. (2007). Autotrophic cultivation of Botryococcus braunii for the production of hydrocarbons and exopolysaccharides in various media. Biomass Bioenergy 31, 87-93. doi:10.1016/j.biombioe.2006.05.001

Devi, M. P., and Venkata Mohan, S. (2012). $\mathrm{CO}_{2}$ supplementation to domestic wastewater enhances microalgae lipid accumulation under mixotrophic microenvironment: effect of sparging period and interval. Bioresour. Technol. 112, 116-123. doi:10.1016/j.biortech.2012.02.095

Devi, M. P., Venkata Subhash, G., and Venkata Mohan, S. (2012). Heterotrophic cultivation of mixed microalgae for lipid accumulation and wastewater treatment during sequential growth and starvation phases. Effect of nutrient supplementation. J. Renew. Energy. 43, 276-283. doi:10.1016/j.renene.2011.11.021

Garbayo, I., Domínguez, M. J., Vigara, J., and Vega, J. M. (2007). Effect of abiotic stress on Chlamydomonas acidophila viability. Appl. Microbiol. 1, 184-189.

Garbayo, I., Cuaresma, M., Vílchez, C., and Vega, J. M. (2008). Effect of abiotic stress on the production of lutein and $\beta$-carotene by Chlamydomonas acidophila. Process Biochem. 43, 1158-1161. doi:10.1016/j.procbio.2008.06.012

Garcia, O. P., Bashan, Y., and Puente, M. E. (2011). Organic carbon supplementation of sterilized municipal wastewater is essential for heterotrophic growth and removing ammonium by the microalgae Chlorella vulgaris1. J. Phycol. 47, 190-199. doi:10.1111/j.1529-8817.2010.00934.x

Gerloff-Elias, A., Barua, D., Mölich, A., and Spijkerman, E. (2006). Temperatureand $\mathrm{pH}$-dependent accumulation of heat-shock proteins in the acidophilic green alga Chlamydomonas acidophila. FEMS Microbiol. 56, 345-354. doi:10.1111/j.1574-6941.2006.00078.x

Giordano, M. (2001). Interactions between C and N metabolism in Dunaliella salina cells cultured at elevated $\mathrm{CO}_{2}$ and high $\mathrm{N}$ concentrations. J. Integr. Plant Biol. 158, 577-581. doi:10.1078/0176-1617-00234

Kalita, N., Baruah, G., Goswami, R. C. D., Talukdar, J., and Kalita, M. C. (2011). Ankistrodesmus falcatus: a promising candidate for lipid production, its biochemical analysis and strategies to enhance lipid productivity. J. Microbiol. Biotechnol. Res. 1, 148-157.

Kumar, A., Ergas, S., Yuan, X., Sahu, A., Zhang, Q., and Dewulf, J. (2010). Enhanced $\mathrm{CO}_{2}$ fixation and biofuel production via microalgae: recent developments and future directions. Trends Biotecnol. 28, 371-380. doi:10.1016/j. tibtech.2010.04.004

Liu, J., Huang, J., Sun, Z., Zhong, Y., Jiang, Y., and Chen, F. (2011). Differential lipid and fatty acid profiles of photoautotrophic and heterotrophic Chlorella zofingiensis: assessment of algal oils for biodiesel production. Bioresour. Technol. 102, 106-110. doi:10.1016/j.biortech.2010.06.017

Merchant, S. S., Kropat, J., Liu, B., Shaw, J., and Warakanont, J. (2012). TAG, you're it Chlamydomonas as a reference organism for understanding algal triacylglycerol accumulation. Curr. Opin. Biotechnol. 23, 352-363. doi:10.1016/j. copbio.2011.12.001

Morales-Sánchez, D., Tinoco-Valencia, R., Kyndt, J., and Martinez, A. (2013). Heterotrophic growth of Neochloris oleoabundans using glucose as a carbon source. Biotechnol. Biofuels 6, 100. doi:10.1186/1754-6834-6-100

Murata, N., Takahashi, S., Nishiyama, Y., and Allakhverdiev, S. I. (2007). Photoinhibition of photosystem II under environmental stress. Biochim. Biophys. Acta 1767, 414-421. doi:10.1016/j.bbabio.2006.11.019

Neale, P. J., and Melis, A. (1989). Salinity-stress enhances photoinhibition of photosynthesis in Chlamydomonas reinbardtii. J. Plant Physiol 134, 619-622. doi:10.1016/S0176-1617(89)80158-0

Perez-Garcia, O., Escalante, F. M. E., de-Bashan, L. E., and Bashan, Y. (2011). Heterotrophic cultures of microalgae: metabolism and potential products. Water Res. 45, 11-36. doi:10.1016/j.watres.2010.08.037
Qiao, H., and Wang, G. (2009). Effect of carbon sources on growth and lipid accumulation in Chlorella sorokiniana GXNN01. Chin. J. Oceanol. Limnol. 27, 762-768. doi:10.1007/s00343-009-9216-X

Sharma, K. K., Schuhmann, H., and Schenk, P. M. (2012). High lipid induction in microalgae for biodiesel production. Energies 5, 1532-1553. doi:10.3390/ en5051532

Subhash, G. V., Rohit, M. V., Devi, M. P., Swamy, Y. V., and Venkata Mohan, S. (2014). Temperature induced stress influence on biodiesel productivity during mixotrophic microalgae cultivation with wastewater. Bioresour. Technol. 169, 789-793. doi:10.1016/j.biortech.2014.07.019

Taguchi, G. (1986). Introduction to Quality Engineering: Designing Quality in to Products and Processes. Tokyo: Asian Productivity Organization.

Talebi, A. F., Tabatabaei, M., Mohtashami, S. K., Tohidfar, M., and Moradi, F. (2013). Comparative salt stress study on intracellular ion concentration in marine and salt-adapted freshwater strains of microalgae. Nat. Sci. Biol. 5, 309-315.

Varshney, P., Mikulic, P., Vonshak, A., Beardall, J., and Wangikar, P. P. (2015). Extremophilic micro-algae and their potential contribution in biotechnology. Bioresour. Technol. 184, 363-372. doi:10.1016/j.biortech.2014.11.040

Vaquero, I., Ruiz-Domínguez, M. C., Márquez, M., and Vílchez, C. (2012). $\mathrm{Cu}$-mediated biomass productivity enhancement and lutein enrichment of the novel microalga Coccomyxa onubensis. Process Biochem. 47, 694-700. doi:10.1016/j.procbio.2012.01.016

Venkata Mohan, S., Chandrasekhara Rao, N., Krishna Prasad, K., Muralikrishna, P., Sreenivasa Rao, R., and Sarma, P. N. (2005). Anaerobic treatment of complex chemical wastewater in a sequencing batch biofilm reactor: process optimization and evaluation of factors interaction using the Taguchi dynamic DOE methodology. Biotechnol. Bioeng. 90, 732-745. doi:10.1002/bit.20477

Venkata Mohan, S., and Devi, M. P. (2014). Salinity stress induced lipid synthesis to harness biodiesel during dual mode cultivation of mixotrophic microalgae. Bioresour. Technol. 165, 288-294. doi:10.1016/j.biortech.2014.02.103

Venkata Mohan, S., Devi, M. P., Mohanakrishna, G., Amarnath, N., Babu, M. L., and Sarma, P. N. (2011). Potential of mixed microalgae to harness biodiesel from ecological water-bodies with simultaneous treatment. Bioresour. Technol. 102, 1109-1117. doi:10.1016/j.biortech.2010.08.103

Venkata Mohan, S., Lalit Babu, V., and Sarma, P. N. (2008). Effect of various pretreatment methods on anaerobic mixed microflora to enhance biohydrogen production utilizing dairy wastewater as substrate. Bioresour. Technol. 99, 59-67. doi:10.1016/j.biortech.2006.12.004

Venkata Mohan, S., Rohit, M. V., Chiranjeevi, P., Chandra, R., and Navaneeth, B. (2015). Heterotrophic microalgae cultivation to synergize biodiesel production with waste remediation: progress and perspectives. Bioresour. Technol. 184, 169-178. doi:10.1016/j.biortech.2014.10.056

Venkata Mohan, S., Sirisha, K., Sreenivasa Rao, R., and Sarma, P. N. (2007). Bioslurry phase remediation of chlorpyrifos contaminated soil: process evaluation and optimization by Taguchi design of experimental (DOE) methodology. Ecotoxicol. Environ. Saf. 68, 252-262. doi:10.1016/j.ecoenv.2007.06.002

Xia, J. R., and Gao, K. S. (2005). Impacts of elevated $\mathrm{CO}_{2}$ concentration on biochemical composition, carbonic anhydrase, and nitrate reductase activity of freshwater green algae. J. Integr. Plant Biol. 47, 668-675. doi:10.1111/j.17447909.2005.00114.x

Zhang, Y. M., Chen, H., He, C. L., and Wang, Q. (2013). Nitrogen starvation induced oxidative stress in an oil-producing green alga Chlorella sorokiniana C3. PLoS ONE 8:69225. doi:10.1371/journal.pone.0069225

Zheng, S. Z., Wang, D. Y., Zhang, Q., and Shen, X. W. (1997). Chemical studies on the polysaccharide from Dunaliella salina (I). J. Northwest Normal Univ. 33, 93-95.

Conflict of Interest Statement: The authors declare that the research was conducted in the absence of any commercial or financial relationships that could be construed as a potential conflict of interest.

Copyright (C) 2016 Chiranjeevi and Venkata Mohan. This is an open-access article distributed under the terms of the Creative Commons Attribution License (CC BY). The use, distribution or reproduction in other forums is permitted, provided the original author(s) or licensor are credited and that the original publication in this journal is cited, in accordance with accepted academic practice. No use, distribution or reproduction is permitted which does not comply with these terms. 